\title{
OPENCAST MINING IN BRITAIN
}

$\mathrm{T}$ HE Opencast Coal Bill, which received a second reading in the House of Lords on June 26, repeals the Defence Regulations under which opencast coal operations are now carried on. In moving the second reading, the Minister of Power, Lord Mills, said that the Bill was the last and largest step in replacing by statutory provisions the Defence Regulations relating to land. The Water Bill and the Land Powers (Defence) Bill had been other measures to that end. Lord Mills said that opencast coal working on a substantial scale began in 1942 to help relieve the acute shortage of coal that had then developed, and since then the opencast sites had produced 160 million tons of coal from slightly less than 110,000 acres, mostly agricultural land, or about 0.25 per cent of our total agricultural land. The opencast output was now about 14 million tons a year, about a quarter of which was large coal, and would fall in two or three years to about 4 million tons unless new sites came into production. To avoid a resumption of imports and replacing restrictions on supplies of house coal we must maintain a substantial level of opencast output for some time and would probably need some opencast coal for the next ten years. Lord Mills assured the House that he would give very close attention to the National Coal Board's plans for opencast coal output with the view of maintaining adequate supplies of coal while doing the minimum damage to agriculture and amenity. In recent months we had been able to defer indefinitely the working of several sites and he hoped the improved position would enable us to be a little more selective.

Lord Mills said that when the new Bill came into operation the National Coal Board intended, whenever possible, to obtain the land or rights in land which they needed for opencast working by agreement, and he gave as one reason for the new legislation the high standard of agricultural restoration after opencast coal working which we had developed. To ensure the maintenance of that high standard we must make special arrangements for close Ministerial control of opencast coal production. He stated categorically that it was the Government's intention at least to maintain present standards of restoration, and, in particular, to require the Board, in the national interest, to restore all agricultural land to the general standard laid down in a code of restoration which was adopted in 1951 and is now being improved as a result of recent discussions between his Department and the National Coal Board and the agricultural organizations. This code provides for five years special treatment of restored agricultural land, and under the Bill the Agricultural Departments would continue to carry out this treatment for the Board, while the Forestry Commission would act similarly for woodland.

In explaining the compulsory powers under the Bill, Lord Mills said that, by Clauses 4 and 6 , the Board was empowered to acquire the rights needed to hold, for up to ten years, land at present held under requisition from opencast coal disposal points and stocking grounds. Clause 9 provided that. no compulsory rights order could be made against an. occupied dwelling house, its garden and certain other land held with it, while every compulsory rights order would be subject to confirmation by the Minister of Power under a procedure which ensured a right to object and to have objection heard. In replying on. the debate, Lord Mills said that he was convinced that it would have been wrong to suggest any shorter period than ten years for the operation of the Bill. He was not entirely satisfied that the Bill adequately covered the possible effect of opencast coal working on water supplies, but the Government did not intend that the powers it conferred should enable the National Coal Board to over-ride the Water Act, 1945, or bye-laws made under that Act.

\section{SYNOPTIC CLIMATOLOGY}

CYNOPTIC climatology provides mean values and $\$$ other statistical parameters of the temperature, cloudiness, precipitation and so on, which are related to the type of air mass and the large-scale distribution of air pressure. It differs in this way from the older type of climatology based more or less exclusively on time of year, which lumped all the atmospheric circulation types together. Types of circulation out. side the tropics are by no means closely related to season, however, though some are more frequent in one season than in another. Moreover, the weather in a given type can differ greatly from one season to another, as is evident from the difference between winter and summer in the effect on temperature over western Europe of a persistent high-pressure area over Scandinavia. Such an area has easterly winds to the south of it.

Knowledge of the weather associated with a given type is essential to the weather forecaster, who works by first predicting the pressure distribution and then the associated weather. These two stages are more clearly marked in the modern numerical method of forecasting based on the approximate solution of the equations of motion of the atmosphere by replacing the differential coefficients by finite differences than in the older and more subjective method.

A notable contribution to the synoptic climatology of the British Isles was Dr. Belasco's "Characteristics of Air Masses over the British Isles" (Meteorological Office Geophysical Memoir, No. 87 ; 1952).

Now the Weather Service of the Federal German Republic has published an even more elaborate synoptic climatological study in Dr. K. Bürger's work, "Zur Klimatologie der Grosswetterlagen, ein witterungsklimatologischer Beitrag"*. This is a truly monumental record of the synoptic climatology of western Germany (including Berlin). Witterung, a useful word for which there is no single equivalent in English, implies "the constant element in a sequence of weather situations over several days", and Gross-

* Berichte des Deutschen Wetterdienstes. Nr. 45 (Band 6): Zur Klimatologie der Grosswetterlagen, ein witterungsklimatologischer Beitrag. Von Kurt Bürger. 79 s. mit 2 Abbildungen und 36 Tabelle $n$ $\mathrm{m}$ Text, sowie 13 Zahlentafeln und 8 Bildtafeln im Anhang. (Offenbach/M.: : Deutschen Wetterdienstes, 1958.) 46.60 D.M. 
wetterlage means "the main constant circulation and main pressure distribution over the area studied during the period for which the weather type (Witterung) persists".

Bürger's work is based on the analysis by punched cards of the observations of temperature, cloud and precipitation at Berlin, Bremen, Karlsruhe and Munich over the period 1890-1954 (omitting 1945). Twenty-eight types of circulation (Grosswetterlage) are distinguished, taken for the period to 1952 from Hess and Brezowsky's 'Katalog der Grosswetterlagen Europas" (Berichte des Deutschen Wetterdienstes U.S.-Zone, Nr. 33 ; 1952).

The statistics of the types and of the elements considered in relation to the types set out in numerous tables and diagrams with seventy-eight large pages of commentary include the monthly means for each type, with deviations from the means, and much additional information-such as the types which bring the earliest and last frosts and snowfalls of the year.
As an example of the seasonal differences in the weather associated with circulation types it is shown in one of the tables that while southerly and south. easterly winds associated with an anticyclone are nearly the coldest at Berlin in winter, with a mean temperature $5^{\circ} \mathrm{C}$. below the seasonal mean, by May they have become warmest, with a mean temperature $3 \cdot 1^{\circ} \mathrm{C}$. above the seasonal mean. There are naturally differences in the effect of different circulation types at the four stations, notably between Bremen and Munich.

The effect of continentality is clearly shown in the dependence of the standard deviations on place and type. The frequency of temperatures and precipitation between specified limits and occasions of extreme values are listed and referred to their circulation type.

There is no discussion of upper air conditions, but perhaps they will be similarly dealt with later.

\title{
EFFECT OF COLCHICINE ON THE UTILIZATION OF LABELLED THYMIDINE DURING CHROMOSOMAL REPRODUCTION
}

\author{
By L. F. La COUR \\ John Innes Horticultural Institution, Eayfordbury, Hertford, Herts \\ AND \\ DR. S. R. PELC \\ Medical Research Council Biophysics Research Unit, King's College, Strand, London
}

\begin{abstract}
T has been accepted that labelled thymidine is incorporated only into deoxyribonucleic acid ${ }^{1}$. Taylor et al. ${ }^{2}$ used thymidine labelled with tritium to provide information on the mode of chromosome replication, and colchicine was employed to assist in clarifying the way in which the tracer was inherited by the daughter chromosomes in the meristematic cells of roots of Vicia faba. Autoradiographs over chromosomes were obtained by the stripping film technique in squash preparations. Taylor and his collaborators grew seedlings in nutrient solution containing thymidine- ${ }^{3} \mathrm{H}$ for $8 \mathrm{hr}$., then transferred the plants to nutrient solution containing a concentration of 0.05 per cent colchicine, and fixed root tips 18 and $42 \mathrm{hr}$. after the start of labelling. Colchicine, by inhibiting spindle formation, allowed them to distinguish with certainty the first $\left(X_{1}\right)$ and second $\left(X_{2}\right)$ mitosis after labelling. $C$-metaphases with the normal complement of 12 chromosomes would be expected in the roots fixed at $18 \mathrm{hr}$. and a high proportion of $C$-metaphases with 24 chromosomes in those fixed after $42 \mathrm{hr}$.

In $C$-metaphases of $X_{1}$ cells they report that both chromatids in each of the 12 chromosomes were equally labelled along their length, while in $C$-metaphases of $X_{2}$ cells usually only one of the chromatids in each of the 24 chromosomes was labelled along its length. A few $X_{3}$ cells (48 chromosomes) were found in roots fixed after $42 \mathrm{hr}$., in which about half the chromosomes were unlabelled, the remainder being labelled in one chromatid. In $X_{2}$ and $X_{3}$ cells a few chromatids were labelled along only part of their length, but in these instances the sister chromatids
\end{abstract}

were labelled in complementary segments. This exchange was attributed to somatic crossing-over.

These findings were interpreted as showing that the, deoxyribonucleic acid is synthesized as an intact unit, and that reproduction in chromosomes which behave as if they consist essentially of one molecule is by means of a template based on a double-helix model, as envisaged by Watson and Crick ${ }^{3}$. In this system each chromatid after replication would consist of two strands, one with 'old' and one with 'new'

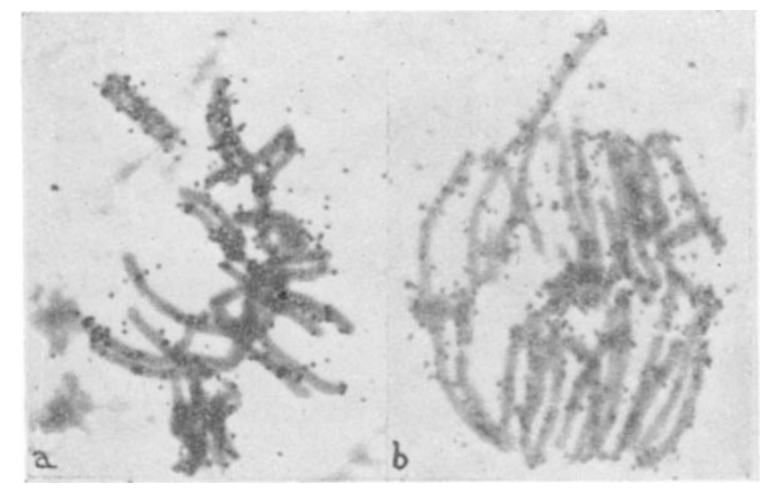

Fig. 1. Autoradicgraph of $X_{2}$ metaphase $(a)$ and $X_{2}$ anaphase (b) from rocts of Vicia faba grown for $12 \mathrm{hr}$. in tap-water containing thynidine ${ }^{3} \mathrm{H}$ followed by $36 \mathrm{hr}$. in pure tap-water. Squash preparations stained in toluidine blue after autoradiography. Note in metaphase labelling in both chromatids of $s$-chromosomes at top left and right, unequal labelling in others and at bottom $(\times 1,300)$ 